\title{
Model funkcjonowania centrum logistycznego w oparciu o Lean Management
}

http://dx.doi.org/10.18778/8142-085-3.05

Katarzyna Bonin, Adrianna Karaś

Akademia Morska w Gdyni

\section{Wstęp}

Szybkość zmian zachodzących w obszarze logistyki wymusza na wielu przedsiębiorstwach, zarówno krajowych, jak i zagranicznych, ciągłość dostosowywania się do potrzeb klienta oraz konkurencyjnego rynku. Globalizacja i nieustanne zmiany rynkowe wywołały potrzebę wprowadzania innowacyjnych rozwiązań w celu poprawy funkcjonowania przedsiębiorstw. Nowoczesne rozwiązania i koncepcje, a przede wszystkim innowacyjne podejście, są niezbędne do zwiększania efektywności systemów logistycznych. Usprawnieniom systemów logistycznych służą różnego rodzaju narzędzia i metody (Koza, Łapuńka, 2014). Jednym z nich jest koncepcja Lean - polegająca na polepszaniu jakości, rozwoju nowych wyrobów, spłaszczaniu struktur oraz utrzymywaniu dobrych stosunków firmy z otoczeniem, wzmacnianiu konkurencyjności. Koncepcja zarządzania Lean Management porównywana jest do krwioobiegu człowieka, tak jak układ krwionośny napędzany skurczami serca, dostarcza krew do żył, tak samo zadaniem systemów logistycznych jest perfekcyjna organizacja oraz ciągła redukcja marnotrawstwa.

\section{Lean Management}

Lean Management to koncepcja, która nie oferuje standardowych wzorców postępowania. Jej głównym założeniem jest zarządzanie bez tworzenia strat. Straty najczęściej generowane są poprzez defekty, zbędne powtarzanie czynności, nadprodukcję, transport, nieuzasadnione procesy, angażowanie zbędnych urządzeń i rozdzielanie zadań na niewłaściwe szczeble lub kierowanie ich do niekompetent- 
nych osób. Niestety, musimy mieć świadomość, że rozwiązanie wszystkich tych problemów jest praktycznie niemożliwe. Do każdego z problemów należy podejść indywidualnie, w sposób systemowy, zgodnie z ustaloną strategią firmy/organizacji (Mateuszek, 2012).

Podchodząc do „odchudzania” zarządzania od strony logistycznej, szczególną uwagę należy zwrócić na:

- sposób wykonywania czynności związanych z realizacją zamówienia,

- potrzebę skracania czasu realizacji zamówienia,

- konieczność zaangażowania pracowników,

- niezbędność ciągłego doskonalenia systemów,

- nakaz eliminowania wszelkiego marnotrawstwa.

Składniki „odchudzonego” zarządzania, które przyczynią się do osiągnięcia sukcesu w przedsiębiorstwach, to (Mateuszek, 2012):

\section{Praca grupowa}

Czynnik ten ma decydujący wpływ na tempo rozwoju przedsiębiorstwa. Praca $\mathrm{w}$ grupie przynosi bardziej owocne efekty niż praca pojedynczej osoby. W przypadku błędu popełnionego przez jedną osobę ktoś z grupy może go „wyłapać”. Aby praca grupy była efektywna, kierownictwo powinno rozliczać ją z jakości świadczonych przez nią usług, harmonogramu czasu realizowanego procesu, a także wytworzonego produktu.

2. Decentralizacja decyzji

Koncepcja Lean Management zastrzega sobie przekazywanie kompetencji decyzyjnych na niższe szczeble struktury organizacyjnej. Wpływa to na autonomię, wyzwala odpowiedzialność za grupę oraz samokontrolę. Przyczynia się do likwidacji średnich szczebli zarządzania. Aby móc wprowadzić taki rodzaj zarządzania, należy podnieść kwalifikacje wykonawców do poziomu pozwalającego na podejmowanie przez nich skutecznych i efektywnych decyzji. Jeżeli osoby z niższego szczebla są wysoko wykwalifikowane, przedsiębiorstwo może generować oszczędności - nie ma potrzeby rotacji pracowników wyższego szczebla, mniejsze są koszty transportu, nadzoru, rozbudowanej administracji.

3. Orientacja na klienta

Należy rozpocząć od analizy potrzeb klienta w odniesieniu do produktów, które mają mu być zaoferowane w przyszłości. Orientacja na wybór klienta jest obecna $\mathrm{w}$ procesie przygotowywania produktu. Usytuowanie przedsiębiorstwa musi być łatwo dostępne zarówno dla klientów zewnętrznych, jak i wewnętrznych.

4. Ciągłe ulepszanie - Kaizen (Kwiatkowska, 2010)

Praktyka ciągłego udoskonalania stanowi ważny filar długofalowej strategii konkurencyjnej. Jest to hasło przewodnie w dążeniu do bycia bezkonkurencyjnym, wywodzi się z Japonii. Podstawą osiągnięcia sukcesu jest przekonanie, że nie ma niczego, co nie mogłoby być udoskonalone oraz dążenie do stanu, w którym wszystkie osoby realizujące dany proces będą dążyć do jego doskonalenia. 
5. Spłaszczona hierarchia

Jeżeli struktura organizacji jest rozbudowana tylko do koniecznego minimum, to łatwiej i sprawniej można prowadzić działalność - ułatwiona jest komunikacja pomiędzy pracownikami, a co za tym idzie wzrasta zainteresowanie klientem.

6. Odrzucenie błędów u źródła

Jak powszechnie wiadomo, błędów nie popełnia tylko ten, który nie dąży do samodoskonalenia. Więc musimy być świadomi, że napotkamy je na każdym etapie rozwoju swojego przedsiębiorstwa. Zgodnie z poglądem mówiącym o tym, że wykrycie i eliminacja błędu najmniej kosztuje w miejscu jego powstania, a najwięcej u klienta, należy do jego wykrycia zaangażować każdego pracownika. Ogromną uwagę należy poświęcić badaniom jakości, które pomagają w ulepszeniu źle funkcjonującego systemu lub procesu.

7. Unikanie rozrzutności i marnotrawstwa

Tworzenie wartości produktu opiera się na eliminacji wszelkiego marnotrawstwa. Marnotrawstwem można określić działania, które nie przyczyniają się do powiększania wartości danego dobra. Zaliczyć do nich można wszelkiego rodzaju zapasy, czasy oczekiwania czy naprawy gwarancyjne.

8. Ciągły przepływ materiałów

Materiał przez cały czas powinien być w ruchu. Tworzenie zapasów to mrożenie kapitału, przez co nie dąży się do dalszego rozwoju. Należy optymalizować procesy produkcyjne, aby wyeliminowane zostały zapasy bezpieczeństwa.

\section{Centra logistyczne - definicja}

Poszukiwanie sposobów ograniczania kosztów pomocniczych dla przedsiębiorstw, a także wzrost znaczenia logistyki w osiąganiu przewagi konkurencyjnej spowodowały, że wśród firm produkcyjnych zwiększyło się zainteresowanie powierzaniem działań logistycznych wyspecjalizowanym usługodawcom. Wpisuje się to idealnie w składowe idei Lean Management. Chcemy ukazać, w jaki sposób zarządzanie centrum logistycznym przyczynia się do „odchudzenia” zarządzania przedsiębiorstwem.

Zaczniemy od klasycznej definicji: „Centrum logistyczne to terytorialnie połączona aktywność organizacji świadczącej usługi logistyczne w punkcie korzystnie usytuowanym w stosunku do odbiorcy, organizująca oraz stymulująca przepływ towarów na obszarze swojej działalności geograficznej lub w danej branży” (Bendkowski, Kramarz, 2011).

Taka kompleksowość świadczonych usług usprawniających działanie przedsiębiorstwa podwyższa ocenę jakości pracy. Usługi logistyczne składają się głównie 
z transportu, spedycji i magazynowania. Centrum logistyczne daje możliwość synchronizacji wszystkich tych procesów w jednym miejscu. Wielkość i struktura centrum logistycznego powinny zostać dostosowane do konkretnych zadań logistycznych, będących funkcją obsługiwanego obszaru, a w szczególności - liczności i charakteru klientów działających na tym obszarze - największy sukces odnosi się w miejscach, gdzie tereny inwestycyjne zasiedlają również firmy produkcyjne skupiające wokół siebie swoich dostawców lub wcześniej obok centrum logistycznego powstał park przemysłowy z odpowiednio dużą liczbą przedsiębiorstw produkcyjnych (Fechner, 2008).

Usługi świadczone przez centra logistyczne posiadają funkcje przede wszystkim przeładunkowe, magazynowe, ale także obejmują szereg innych funkcji logistycznych, takich jak: obsługa środków transportu, wynajem, czynsz, naprawa opakowań transportowych, usługi informatyczne, finansowe i inne. Jak widzimy, tego typu centra to obiekty o bardzo wysokim stopniu złożoności. Co za tym idzie, tworzenie tego typu obiektów niesie ze sobą szereg problemów natury funkcjonalnej. Wybory lokalizacji oraz wyposażenia bardzo często dokonywane są w sposób chaotyczny i pozbawiony poprzedzających obserwacji. Bez wyspecjalizowanych badań trudno dobrać parametry i funkcje lokalizacji i wyposażenia, aby prowadziły one do optymalizacji późniejszych procesów zachodzących w centrach.

Chcąc stworzyć model centrum logistycznego opierającego się na koncepcji Lean Management, należy postawić następujące wymagania (Cisowski, 2012):

- dążenie do optymalizacji procesów,

- synergia wszystkich procesów w działalności centrum w celu zaspokojenia potrzeb uczestników łańcucha dostaw,

- minimalizacja kosztów,

- adaptacja do warunków zewnętrznych,

- możliwość rozbudowy modelu,

- zapewnienie optymalnej współpracy pomiędzy sąsiednimi ogniwami łańcucha dostaw.

Przedsiębiorstwa zmuszone są do obniżania kosztów działalności ze zwiększoną efektywnością, co wymaga od nich obserwacji każdego procesu logistycznego. Operacje logistyczne, takie jak magazynowanie, transport wewnętrzny, kompletacja i paletyzacja zamówień, wymagają dużych nakładów pracy, zatrudnienia wielu pracowników lub zachowania niezrównanej precyzji załadunków. Koszty obsługi procesów logistycznych rosną niewspółmiernie wraz ze zwiększaniem się liczby obsługiwanych jednostek, asortymentu, dostawców i klientów. Wszystkie tego typu operacje mogą być przeprowadzone w jednym miejscu w celu ich usprawnienia - w centrum logistycznym. W tym przypadku konieczne jest zoptymalizowanie kosztów operacyjnych działalności i usprawnienie procesów. Niezbędne jest wdrożenie czynnika automatyzacji. Automatyczne układnice magazynowe i urządzenia transportu wewnętrznego zapewniają szybką i bezpieczną obsługę ładunków. Połączenie przenośnikami stref magazynowania, kompletacji, pakowania 
i ekspedycji umożliwia równoczesną realizację wielu zamówień z zachowaniem małej liczby błędów wydań. Systemy automatycznego sortowania dbają o szybkie i bezbłędne kierowanie jednostek ładunkowych czy pojedynczych produktów do właściwych punktów docelowych. Systemy informatyczne we współpracy z systemami automatyki przejmują rolę synchronizowania fizycznych przepływów towarów ze stowarzyszonymi z nimi przepływami i przetwarzaniem informacji oraz precyzyjnej obsługi rozbudowanych baz danych (Michalski, 2008).

\section{Centra logistyczne w Europie}

Europejskie centra logistyczne na przestrzeni lat kształtowały się w rozmaity sposób, a ich geneza sięga odległych lat. Znaczenie logistyki i działalności transportowej, a także globalizacja gospodarcza, spowodowały przyjęcie polityki rozwoju centrów logistycznych przez państwa europejskie. W Europie nie ma ujednoliconego nazewnictwa obszarów takich jak centra logistyczne. Wyróżniamy ich cztery typy (Fechner, 2008):

- francuskie Plateforme Logistique, Centres Routiers lub Gares Routieres

Od 1979 r. SNCF (Société nationale des chemins de fer français) (z franc. Narodowe Towarzystwo Kolei Francuskich) podjęło się pewnego rodzaju eksperymentu, założenie opierało się na przekształceniu pięciu zdekoncentrowanych stref przewozów w rejony usług logistycznych. Do realizacji wykorzystano stacje wielofunkcyjne (gare multifunctions), wokół których rozwinięto sieć usług dystrybucyjnych. Tego typu rozwiązanie umożliwiło zachowanie i eksploatację linii o małej intensywności przewozów towarowych. Funkcjonujące ośrodki usług są otwarte bezustannie, a ich zadaniem jest organizacja, zbiórka i ekspedycja pojedynczych wagonów, dostępnych także dla przewoźników samochodowych. Usługi te mają charakter nieregularny i zależny od częstości oraz godzin ich wykonywania, a wszelkiego rodzaju warunki są omawiane z klientami indywidualnie. Przewozy według schematycznego „rozkładu jazdy” zostają wyparte przez przewozy regulowane według popytu.

\section{- brytyjskie Freight Village}

Tunel pod kanałem La Manche zmienił diametralnie sytuację pomiędzy transportem drogowym a kolejowym. Jak podaje Fechner, „Według prognoz, stałe połączenia z dużymi ośrodkami przemysłowymi na kontynencie skróciły średnio o ponad 24 godziny czas dostawy ladunku. Przeprowadzone obserwacje przewozu ładunków transportem kolejowym i samochodowym w systemie dom-dom 
między Manchesterem a Mediolanem wykazały, że czas przewozu koleją wynosi 37 godzin, natomiast wyłącznie transportem samochodowym - 60 godzin" (Fechner, 2008). Brytyjska koncepcja centrum logistycznego zakłada oferowanie usług przeładunkowych, magazynowych, dystrybucyjnych i przewozowych na obszarach prowadzących do centrum. Rozwój każdego centrum logistycznego winien dokonywać się dzięki udziałowi spółek prywatnych. Do realizacji przedsięwzięć takich jak centra brytyjskim inwestorom potrzebny jest kapitał krajowy, jak i zagraniczny. Dotychczasowe centra logistyczne i ich realizacja odbywała się dzięki prywatnym spółkom, które były w stanie finansować projekty techniczne i brać udział w rozwoju obiektów infrastruktury kolejowej. Przeprowadzone badania i analizy rynku przewidują, że całkowite zagospodarowanie terenów na centra logistyczne nastąpi w ciągu 15-20 lat.

- niemieckie Guterverkehrszentrun (GVZ)

Niemieckie centra logistyczne opierają się na założeniach usprawnień układu przestrzennego i funkcjonalnego aglomeracji miejskich. Model budowy centrów logistycznych posiada poparcie sektora publicznego, a zatem protekcję $\mathrm{w}$ ustawach i prawie. Niemiecki rządowy plan projektów centrów logistycznych zakłada finansowanie i pomoc dzięki budżetowi federalnemu, który pokrywa koszty terminali kontenerowych. To właśnie dzięki Deutsche Bahn AG, który także wspiera budowę centrów logistycznych w ramach dotacji i pożyczek zwrotnych dla konkretnych inwestycji, ten obszar logistyki jest prężnie rozwijany w Niemczech. Wsparcia finansowego inwestycjom $\mathrm{w}$ centra udzielają także kraje związkowe i samorządy lokalne, natomiast mocną stroną $\mathrm{w}$ niemieckich inwestycjach jest sektor publiczny. Efektem wsparcia przez sektor publiczny w Niemczech i nacisku na rozwój są licznie powstające centra logistyczne.

- włoskie Interporto

Włoskie centra logistyczne odznaczają się pewnego rodzaju podobieństwami, charakteryzuje je określony sposób, w jaki były i nadal są realizowane. Pierwszą i najważniejszą kwestią jest to, że budowa centrów logistycznych posiada wsparcie rządu włoskiego i odbywa się zgodnie z planami rządowymi, wspieranymi działaniami legislacyjnymi i publicznymi środkami finansowymi, podobnie jak to dzieje się w Niemczech. Inicjatorem tego typu inwestycji jest sektor publiczny, jednakże w przedsięwzięcia angażują się wspólnie samorządy lokalne i regionalne, a także izby gospodarcze i handlowe. W budowie centrów logistycznych uczestniczy sektor prywatny, który na mocy specjalnej ustawy został dopuszczony do środków publicznych, natomiast obok instytucji sektora publicznego akcjonariuszami spółek budujących centra są włoskie koleje i inni operatorzy logistyczni, jak przewoźnicy i spedytorzy, banki, firmy ubezpieczeniowe oraz firmy transportowe. Do tej pory włoskie centra logistyczne nie miały problemów z pozyskaniem użytkowników, a obecnie kolejne inwestycje w tym obszarze kierują się na południe Włoch. 


\section{Rozwój centrów logistycznych w Polsce}

Jak dowodzi raport „Rozwój Sieci Nieruchomości Logistycznych w Europie”, opracowany przez Prologis we współpracy z Eyefortransport (EFT), centralna Polska jest najbardziej pożądaną lokalizacją tworzenia centrów logistycznych w Europie Środkowo-Wschodniej. Kolejne miejsca w rankingu zajmują Stambuł w Turcji, Praga w Czechach, Bukareszt w Rumunii i Budapeszt na Węgrzech. Paweł Sapek, vice president senior i country manager Prologis na Polskę ${ }^{1}$, dowodzi, że wyniki ostatnich badań przeprowadzonych w Europie ewidentnie pokazują trend zmiany kierunków dostaw w rejon Europy Centralnej. Ma na to wpływ kilka czynników: dostępność siły roboczej, dostępność gruntów inwestycyjnych, jak również koszt zarówno nieruchomości, jak i koszt pracowników. Polska uważana jest za obszar spełniający kryteria bardzo dobrej lokalizacji w odniesieniu do sieci dróg ekspresowych i autostrad. Centrum kraju cieszy się szczególnym zainteresowaniem ze strony potencjalnych akcjonariuszy, jest to rejon (tzw. złoty trójkąt logistyczny): Łódź, Stryków i Piotrków Trybunalski. Podstawą decyzji o budowie centrów logistycznych jest ich odpowiednia lokalizacja. Przy ostatecznym wyborze lokalizacji centrum logistycznego inwestorzy kierują się rozmaitymi wskaźnikami, do których zaliczamy wielkość produktu krajowego brutto, siłę nabywczą ludności, wskaźnik bezrobocia, cenę za $\mathrm{m}^{2}$ gruntów, średnią cenę usług transportowych, koszt dostępu do infrastruktury, ulgi podatkowe, długoterminowe prognozy demograficzne ${ }^{2}$.

\section{Automatyzacja zgodna z filozofią Lean Management}

FM Logistic jest dostawcą usług logistycznych dla przemysłu i firm dystrybucyjnych. Firma ta nieprzerwanie szuka innowacyjnych rozwiązań, aby móc sprostać wyzwaniom w zarządzaniu łańcuchem dostaw i potrzebom swoich klientów. W tym celu, w ramach Grupy FM Logistic utworzono Dział Automatyzacji, który wspólnie z klientami i firmami partnerskimi opracował innowacyjne rozwiązania wspierające proces logistyczny. Wśród nowatorskich metod zaprojektowanych przez firmę warto wyróżnić (Pologne, 2016):

1 http://newsrm.tv/polska-wyprzedzila-czechy-i-wegry-raport-o-rozwoju-centrow-logistycznych/ [dostęp 05.05.2016].

2 http://logistyczna.blogspot.com/ [dostęp 29.05.2016]. 
1. „Moduł rozcinania opakowań zbiorczych"

Otwieranie opakowań zbiorczych podczas operacji copackingu jest czynnością, która może stanowić źródło dolegliwości mięśniowo-szkieletowych (MSD) i skaleczeń. W centrum logistycznym FM Logistic w Fauverney tego typu działaniom poddawanych jest 1,2 miliona opakowań rocznie. Dział Automatyzacji FM Logistic zaprojektował urządzenie pomocne w zadaniach takich, jak:

- możliwość rozcinania opakowań na różnych wysokościach, bez uszkodzenia ich zawartości;

- usuwanie pyłu powstającego podczas rozcinania opakowań;

- kompaktowe urządzenie, łatwe w transporcie na terenie całego magazynu;

- możliwość równoczesnej obsługi kilku linii pakujących;

- stworzenie intuicyjnego dla użytkownika interfejsu.

Axys Robotique to ekspert w zakresie integracji zrobotyzowanych linii pakujących. W efekcie współpracy FM Logistic i Axys Robotique powstał moduł zawierający narzędzie tnące dostosowujące się do grubości i jakości rozcinanego kartonu, o prostym programowaniu i intuicyjnej obsłudze, zapewniające bezpieczeństwo użytkowania. Zastosowanie urządzenia pozwoliło na zwiększenie produktywności copackingu, a także wyeliminowało konieczność otwierania opakowań przez pracowników, co doprowadziło do polepszenia warunków pracy.

2. "Zrobotyzowane ramię"

W celu zbadania możliwości zrobotyzowanego ramienia i adaptacji go do potrzeb operacji pakowania w każdym z centrów FM Logistic, Dział Automatyzacji zaprojektował moduł wyposażony w zestaw opcji i narzędzi chwytających, o niewielkich rozmiarach i wadze, tak aby można było go samodzielnie załadować na pojazd magazynowy. Pierwsze zastosowanie nowatorskiego urządzenia miało miejsce w centrum logistycznym w Neuville-aux-Bois. Urządzenie wyposażone zostało $\mathrm{w}$ dwa zrobotyzowane ramiona i zespolone przenośniki wykonujące permanentne czynności: pierwsze ramię zdejmuje osłonę z opakowania „gotowego do sprzedaży" i odkłada ją na przenośnik odpadów. Natomiast drugie ramię chwyta równocześnie 6 produktów i odkłada je na przenośnik partiami po 2 lub 3 , $\mathrm{w}$ celu podania do etykieciarki.

\section{3. „Robot kartezjański”}

Przygotowanie produktu do sprzedaży detalicznej wiąże się z pakowaniem mniejszych bądź większych kartonów, co również może prowadzić do powstania dolegliwości mięśniowo-szkieletowych u pracowników. Jeśli gabaryty produktów są duże, to załadunek paletowy jest również duży. W związku z tym platforma FM Logistic we współpracy z integratorem systemowym Automat System zaprojektowała dostosowany do swoich potrzeb przemysłowy robot kartezjański, scalony z układem obsługiwanych przez sterownik przenośników. Robot kartezjański 
zapewnia automatyzację rozładunku palet przy dowolnym rozkładzie jej warstw, dodatkowo przy równoczesnym zasilaniu jednej lub kilku linii pakowania. Automatyzacja procesu powoduje zmniejszenie wielkości zapasów na początku i na końcu linii oraz skrócenie czasu oczekiwania na pierwszym stanowisku pakowania, wyeliminowano również czynność depaletyzacji, a także ręcznego przenoszenia ładunków.

4. „Scentralizowane gniazdo owijania palet”

W centrum logistycznym FM Logistic w Fauverney każdego roku zużywa się 4,5 miliona metrów bieżących folii do owijania palet. W celu dopełniania owijarek ręcznych oraz ułatwienia fizycznej czynności związanej z foliowaniem ładunków, Dział Automatyzacji opracował w pełni zautomatyzowane urządzenie dostosowane do owijania palet dowolnego kształtu i wielkości. Gniazdo owijania stanowią przede wszystkim dwie automatyczne owijarki z igłową perforacją folii, umieszczone na przenośniku wyposażonym w obrotowe stoły. Rozmieszczone czujniki instynktownie rozpoznają wymiary podstaw palet.

Moduł rozcinania opakowań zbiorczych, depaletyzator kartezjański, scentralizowane gniazdo owijania palet, zrobotyzowane ramię - wszystkie te innowacyjne rozwiązania pozwalają FM Logistic oferować swoim klientom najwyższą jakość usług. Firma dzięki elastyczności swojego działania łączy mobilność urządzeń z łatwością adaptacji swoich innowacyjnych rozwiązań, dzięki czemu zapewnia klientom „zaopiekowanie się” ich ładunkami od fazy koncepcyjnej po wstawianie towarów na regały sklepowe.

\section{Podsumowanie}

Poniżej stworzyłyśmy zestawienie podstawowych wymagań dotyczących zadań logistycznych, które musi spełnić centrum logistyczne, aby działało efektywnie, w zgodzie z podstawowymi hasłami koncepcji Lean Management odnoszącymi się do poszczególnych procesów (zob. tab. 1).

Jak widzimy na przykładzie zestawienia zaprezentowanego w tabeli 1 , fundamentalne hasła Lean Management znajdują odzwierciedlenie w podstawowych wymaganiach, które musi spełnić centrum logistyczne. Może być ono jednostką autonomiczną, której obsługa procesów logistycznych stanowi podstawę działalności, jak i jednostką wewnętrzną dużego przedsiębiorstwa produkcyjnego.

Centra logistyczne w konsekwencji realizowania swoich zadań stają się obiektami wprowadzania nowoczesnych koncepcji i metod zarządzania. Sprawna realizacja zadań obejmuje całościowy, skomplikowany system logistyczny. 
Tabela 1. Zestawienie podstawowych wymagań dotyczących zadań logistycznych

\begin{tabular}{|c|c|c|}
\hline Zadania logistyczne & Podstawowe wymagania & Zasady Lean Management \\
\hline Składowanie & $\begin{array}{l}\text { - optymalne wykorzystanie } \\
\text { dostępnej przestrzeni } \\
\text { magazynowej } \\
\text { - szybki dostęp do dowolnej } \\
\text { jednostki ładunkowej } \\
\text { - bezpieczeństwo danych, } \\
\text { tadunku i personelu }\end{array}$ & $\begin{array}{l}\text { - odrzucenie błędów u źródła } \\
\text { - unikanie rozrzutności } \\
\text { i marnotrawstwa } \\
\text { - decentralizacja decyzji }\end{array}$ \\
\hline $\begin{array}{l}\text { Przyjęcia zewnętrzne } \\
\text { (surowce, półprodukty, } \\
\text { opakowania) }\end{array}$ & $\begin{array}{l}\text { - minimalizacja błędów } \\
\text { obsługi } \\
\text { - minimalizacja czasu realizacji } \\
\text { zleceń }\end{array}$ & $\begin{array}{l}\text { - spłaszczona hierarchia } \\
\text { - decentralizacja decyzji } \\
\text { - ciągły przepływ materiałów }\end{array}$ \\
\hline $\begin{array}{l}\text { Kompletacja zamówień } \\
\text { i pakowanie }\end{array}$ & $\begin{array}{l}\text { - bezpieczeństwo danych, } \\
\text { tadunku i personelu }\end{array}$ & - orientacja na klienta \\
\hline Ekspedycja & $\begin{array}{l}\text { - elastyczność operacyjna } \\
\text { (dynamiczna kompletacja) }\end{array}$ & - praca grupowa \\
\hline
\end{tabular}

Źródło: opracowanie własne na podstawie Matuszek, 2012; Michalski, 2008.

Centra jako ważne elementy infrastruktury logistycznej stanowią fundamentalny element kształtowania efektów końcowych procesów logistycznych. Potrzeba inwestowania w zakresie logistyki oraz poszukiwanie najbardziej innowacyjnych rozwiązań i koncepcji są niezbędne w tworzeniu ciągu przepływu materiałowego. Jest to zadanie złożone $\mathrm{z}$ wielu etapów, a jednocześnie trudne zwłaszcza w obecnych nieustannie zmieniających się uwarunkowaniach rynkowych.

\section{Bibliografia}

Bendkowski J., Kramarz M., (2011), Logistyka stosowana. Metody, techniki, analizy, cz. II, Wydawnictwo Politechniki Śląskiej, Gliwice.

Cisowski T., (2012), Wielokryterialny model i algorytm optymalizacji centrów logistycznych, „Postępy Nauki i Techniki”, nr 13.

Fechner I., (2008), Centra logistyczne w Europie, Instytut Logistyki i Magazynowania.

Fechner I., (2010), Centra logistyczne i ich rola w procesach przepływu ładunków w systemie logistycznym Polski, Instytut Logistyki i Magazynowania, Centrum Wiedzy Logistycznej.

Innowacyjne rozwiq̨zania w automatyzacji - FM Logistic buduje maszyny przyszłości, (2016), http://www.fmlogistic.pl/Media/Aktualnosci/Innowacyjne-rozwiazania-w-automatyzacjiFM-Logistic-buduje-maszyny-przyszlosci, Pologne [dostęp 01.05.2016]. 
Koza A., Łapuńka I., (2014), Lean Manufacturing jako koncepcja usprawniania procesów w logistyce produkcji - case study, „Logistyka”, nr 6.

Kwiatkowska A., (2010), Kaizen we wspótczesnym przedsiębiorstwie, http://e-bmp.pl/File/ bmp_4c591a4fa569b.pdf [dostęp 20.05.2016].

Matuszek J., (2012), Logistyka produkcji, Wydawnictwo Uczelniane im. Angelusa Silesiusa w Wałbrzychu.

Michalski A., (2008), Rola zautomatyzowanych centrów logistycznych w nowoczesnych procesach tańcucha dostaw, Grupa Emax.

Polska wyprzedziła Czechy i Węgry. Raport o rozwoju centrów logistycznych, (2016), http://newsrm.tv/polska-wyprzedzila-czechy-i-wegry-raport-o-rozwoju-centrow-logistycznych/ [dostęp 05.05.2016].

Wybór lokalizacji centrum dystrybucyjnego, (2013), http://logistyczna.blogspot.com/ [dostęp 29.05.2016]. 